БОЧКАЕВ Алу Ризванович - студент 2-го курса магистратуры факультета социологии и политологии Финансового университета при Правительстве РФ (125993, Россия, г. Москва, Ленинградский пр-кт, 49; dzyudoistalu@mail.ru)

\title{
ОСОБЕННОСТИ И СРАВНИТЕЛЬНЫЕ ХАРАКТЕРИСТИКИ ПОЛИТИЧЕСКИХ КАМПАНИЙ В МОСКВЕ И САНКТ-ПЕТЕРБУРГЕ
}

\begin{abstract}
Аннотация. В России в 2021 г. состоятся выборы в Государственную думу, в связи с чем необходимо вспомнить мероприятия, проходившие в рамках крупных региональных выборов прошлых лет. Выборы губернатора Санкт-Петербурга (2019 г.) стали мероприятием, когда в условиях протестных настроений (в т.ч. из-за пенсионной реформы) представитель «Единой России» одержал победу, однако в советах муниципальных образований значительно усилилась конкуренция. На выборах в Мосгордуму (2019 г.) в Москве значительно увеличили свое представительство КПРФ, «Яблоко» и “Справедливая Россия» при сохранении абсолютного большинства «Единой России». Также на этих выборах началась практика дистанционного электронного голосования (ДЭГ), которая стала новой технологией практики административного ресурса
\end{abstract}

Ключевые слова: выборы, Мосгордума, муниципальные округа, электронное голосование, административный ресурс

A ктуальностьданной статьи связанас будущими выборами в Государственную думу в 2021 г. В рамках данного события имеют значение избирательные кампании, обладающие своими отличительными особенностями и общими характеристиками. Особенности политических (избирательных) кампаний можно рассмотреть на примере Санкт-Петербурга и Москвы - одних из важнейших регионов страны, которые в последние два года отметились крупными избирательными кампаниями (муниципальные выборы в Санкт-Петербурге параллельно с выборами губернатора города, а также выборы в Московскую городскую думу).

Для начала необходимо рассмотреть механизм работы избирательных кампаний. Политическая кампания, также известная как избирательная, - это совокупность агитационных мероприятий кандидатов и политических партий в избирательной борьбе с целью обеспечить как можно большее число голосов на выборах ${ }^{1}$. В предвыборной кампании могут участвовать группы поддержки в виде общественных организаций и СМИ. Основным предвыборным мероприятием становится агитация, в рамках которой печатаются агитационные материалы, статьи и предвыборные афиши, проходят предвыборные собрания и митинги, фиксируются выступления кандидата в СМИ.

Большую роль в избирательных кампаниях играют политтехнологи, которые отличаются широким направлением деятельности - от построения стратегии избирательной кампании до анализа предвыборных речей кандидатов. Регулирование избирательной кампании проходит с помощью избирательного законодательства. Законодательство может регулировать сроки, порядок проведения кампании (в т.ч. агитационные мероприятия), источники финансирования.

Особенности российских избирательных кампаний выглядят следующим

1 Избирательная кампания. - Большой юридический словарь (под ред. А.Я. Сухарева, В.Е. Крутских). М.: Инфра-М. 2003. 
образом. Их отличают серьезное влияние финансовой поддержки и административного ресурса. Фонд поддержки социальных исследований «Хамовники» в результате исследований ${ }^{1}$ выделяет «жесткую» и «мягкую» модели применения административного ресурса.

В рамках «жесткой» модели существует большая ориентация на результат и определенные показатели, из-за чего даже фиктивная конкуренция на выборах резко снижается. Действующая власть на различных уровнях для достижения целевых показателей может проводить мобилизацию бюджетников, силовиков и студентов [Барсукова, Ионова, Сафиуллина 2020]. Для власти достоинствами «жесткого» административного ресурса могут быть гарантии высокой явки и серьезная гарантия победы «своего» кандидата. Однако при данном сценарии существует один серьезный недостаток: при упущении формирования конкуренции административный ресурс в «жестких» формах может не работать, т.к. допускаются реальные влиятельные политические игроки ${ }^{2}$. В условиях расширения доступа к информации недостатки «жесткого» административного ресурса еще усиливаются.

«Мягкая» модель предполагает большее значение финансового ресурса в связи с допуском большего числа кандидатов - как реальных претендентов на победу на выборах, так и спойлеров. Аналогичное утверждение справедливо и для партий. Таким образом, расширяются возможности для не связанных с властью кандидатов в финансовом плане ${ }^{3}$. В рамках этой модели развивается активность политтехнологов, которая формируется как благодаря прямым заказам администрации Президента, так и в связи с установлением коммуникаций с региональными властями. Преимуществом «мягкого» административного ресурса для власти становится возможность создания имиджа определенных выборов как конкурентных. Эта тенденция может развиваться без применения «жестких» вариантов административного ресурса. Дополнительное преимущество - возможность выигрыша кандидата, выгодного власти, в связи с большим числом спойлеров, которые могут отнимать друг у друга протестные голоса. Однако у «мягкого» административного ресурса есть и недостатки, представленные слабым контролем явки и возможностью упущения значимых конкурентов с вероятностью победы, которая может быть далеко не самой низкой.

Таким образом, административный ресурс как метод влияния на результаты выборов, в т.ч. в период избирательных кампаний, отличается разнообразием и имеет свои достоинства и недостатки. В условиях более интенсивного распространения информации более актуальной становится «мягкая» практика административного ресурса, однако свое значение сохраняют и традиционные («жесткие») мероприятия в этой области. Административный ресурс - один из способов сохранения статус-кво со стороны действующей власти.

Одни из самых конкурентных избирательных кампаний в 2019 г. прошли в

1 Завершен второй этап проекта «Неформальные практики организации и проведения избирательных кампаний в современной России». - Хамовники. Доступ: http://khamovniky. $\mathrm{ru} /$ zavershen-vtoroj-etap-proekta-neformalnye-praktiki-organizacii-i-provedeniya-izbiratelnyxkampanij-v-sovremennoj-rossii/ (проверено 26.03.2021).

2 «Скумбрия против всех». Когда политика становится фарсом, люди превращают ее в карнавал. - Деловой квартал. Екатеринбург. Доступ: https://ekb.dk.ru/news/regionyvosprinimayutsya-kak-nedomoskva-eto-kak-budto-vcherashniy-den-moskvy-237113785 (проверено 26.03.2021).

3 Завершен второй этап проекта «Неформальные практики организации и проведения избирательных кампаний в современной России». - Хамовники. Доступ: http://khamovniky. $\mathrm{ru} /$ zavershen-vtoroj-etap-proekta-neformalnye-praktiki-organizacii-i-provedeniya-izbiratelnyxkampanij-v-sovremennoj-rossii/ (проверено 26.03.2021). 
двух столицах - Москве и Санкт-Петербурге. В Москве проходили выборы в Московскую городскую думу, в Санкт-Петербурге - выборы губернатора и муниципальные выборы. Конкурентность московской кампании оценили политические обозреватели Елена Мухаметшина и Анастасия Корня ${ }^{1}$. Самым громким поражением «Единой России» стало выбывание главы московского отделения партии Андрея Метельского в одномандатном округе № 15. Мэр Москвы Сергей Собянин также охарактеризовал выборы как конкурентные 2 .

Особенностью московских городских выборов (2019 г.) стало электронное голосование. Электронное голосование прошло в трех избирательных округах: № 1 (Зеленоград, а именно районы внутри него), № 10 (Северный - бывший поселок, Бибирево, Лианозово), № 30 (Чертаново Центральное и Чертаново Южное). Безопасность процесса и полную анонимность избирателей обеспечивают технологии блокчейна ${ }^{3}$. При помощи анонимайзера при голосовании пользователь получает электронный бюллетень, на котором он может проголосовать. Результаты эксперимента электронного голосования (далее - ЭГ) кардинально отличались: $90 \%$ составила явка на ЭГ и лишь $21,77 \%$ - на обычных выборах ${ }^{4}$.

ЭГ как форма голосования на выборах оценивается крайне неоднозначно. Заместитель руководителя департамента информационных технологий Москвы Артем Костырко объясняет высокую явку на ЭГ высокой оценкой избирателями данной системы ${ }^{5}$. В то же время кандидат от одномандатного округа № 30 Роман Юнеман обозначил, что ЭГ - «новая жизнь административного ресурса» и что решение о введении ДЭГ (дистанционного электронного голосования) было политическим решением, реализация которого про-

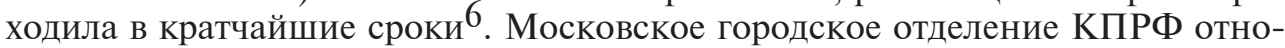
сится к электронному голосованию скептически: кризис доверия к власти - не время вводить электронное голосование на выборах 7 .

Другой особенностью московских выборов (2019 г.) стал резкий рост представительства КПРФ и спад числа мест «Единой России» (см. табл. 1). Представители «Единой России» проходили как самовыдвиженцы, поддержанные этой партией и мэрией Москвы. Укрепление позиций КПРФ связано с протестным голосованием, в т.ч. с проектом «Умное голосование».

В Санкт-Петербурге 8 сентября 2019 г. избирательная кампания отметилась двойными выборами - губернаторскими и муниципальными. На губернаторских выборах проявилась довольно высокая конкуренция, однако с предсказуемой победой Александра Беглова. За три дня до выборов Александр Беглов отметился грамотным управленческим решением - не открывать три новые станции метро («Проспект Славы», «Дунайская», «Шушары») из соображе-

\footnotetext{
1 Мухаметшина Е., Корня А. На выборах в Мосгордуму победили Навальный и его «умное голосование». - Ведомости. Доступ: https://www.vedomosti.ru/politics/ articles/2019/09/09/810870-viborah-mosgordumu (проверено 20.03.2021).

2 Там же.

3 В Москве впервые проходит электронное голосование. - Официальный сайт мэра Москвы. Доступ: https://www.mos.ru/news/item/61764073/ (проверено 26.03.2021).

4 Накликали победу. Итоги электронного голосования в Москве подтвердили - за этим будущее. - Российская газета. Доступ: https://rg.ru/2019/09/09/reg-cfo/v-moskve-podveliitogi-eksperimenta-s-elektronnym-golosovaniem.html (проверено 26.03.2021).

5 Там же.

6 Электронное голосование. Риски и уязвимости. Доступ: https://evoting.ru/ (проверено 23.03.2021).

7 Общество не готово к электронному голосованию. - Московское городское отделение Коммунистической партии Российской Федерации. Доступ: https://msk.kprf.ru/2019 /09/10/125338/ (проверено 23.03.2021).
} 
Таблица 1

Результаты выборов в Мосгордуму в 2014 и 2019 гг.

\begin{tabular}{|l|c|c|c|}
\hline \multicolumn{1}{|c|}{ Партия } & Число мест в 2014 г. & Число мест в 2019 г. & Изменения \\
\hline «Единая Россия» & 38 & 24 & -14 \\
\hline КПРФ & 5 & 13 & +8 \\
\hline «Яблоко» & 0 & 4 & +4 \\
\hline «Справедливая Россия» & 0 & 3 & +3 \\
\hline ЛДПР & 1 & 0 & -1 \\
\hline «Родина» & 1 & 0 & -1 \\
\hline
\end{tabular}

Таблица 2

Результаты муниципальных выборов в Санкт-Петербурге в 2014 и 2019 гг.*

\begin{tabular}{|l|c|c|c|c|}
\hline Партия & $\begin{array}{c}\text { Число мест } \\
\text { в 2014 г. }\end{array}$ & $\begin{array}{c}\text { Число мест } \\
\text { в 2019 г. }\end{array}$ & Изменения & $\begin{array}{c}\text { Число муниципальных } \\
\text { округов с выигрышем }\end{array}$ \\
\hline «Единая Россия» & 1187 & 957 & -230 & 70 \\
\hline Самовыдвиженцы & 200 & 258 & +58 & 6 \\
\hline «Справедливая Россия» & 78 & 108 & +30 & $3(+1)$ \\
\hline «Яблоко» & 0 & 85 & +85 & 2 \\
\hline КПРФ & 24 & 72 & +48 & 1 \\
\hline Партия Роста & 0 & 42 & +42 & 1 \\
\hline
\end{tabular}

* Выборы не проводились в муниципальном округе Автово (Кировский район), где 16 мест из 20 выиграли представители «Справедливой России».

ний безопасности ${ }^{1}$. Особенностью его избирательной кампании стал короткий срок пребывания на посту врио (с октября 2018 по сентябрь 2019), из-за чего серьезных мероприятий (кроме более позднего открытия новых станций метро из соображений безопасности) он провести не успел. Акцент предстояло делать на будущих достижениях ${ }^{2}$, что резко контрастировало с кампаниями московских депутатов и кандидатов в депутаты: они делали акцент на прошлых событиях (это объяснялось сроками пребывания на своих постах).

Результаты выборов при явке в 30,07\% оказались следующими. Александр Беглов получил 64,43\% голосов, Надежда Тихонова («Справедливая Россия») - 16,84\%, Михаил Амосов («Гражданская платформа») - 16,03\%.

Параллельно с губернаторскими выборами в Санкт-Петербурге прошли муниципальные выборы, где «Единая Россия» сохранила лидерство во многих советах муниципальных образований (см. табл. 2). Спад популярности «Единой России» снова оказался связанным с протестным голосованием, не

1 Как Беглов решил не открывать три новые станции метро. - The Village. Доступ: https:// www.the-village.ru/city/situation/361395-metro-open-close (проверено 23.03.2021); Беглов открыл три новые станции метро, но пассажиров на них не пустят. - Интерфакс. Доступ: https://www.interfax.ru/russia/675281 (проверено 23.03.2021).

2 Избирательная кампания Беглова разбудила город трех революций. - Независимая газета. Доступ: https://www.ng.ru/politics/2019-01-29/1_7494_beglov.html (проверено 23.03.2021). 
в последнюю очередь вызванным пенсионной реформой (2018 г.). В период с 8 по 24 сентября 2019 г. поступило более 1,6 тыс. жалоб ${ }^{1}$.

Важным отличием муниципальных выборов в Санкт-Петербурге от выборов в Мосгордуму стало широкое представительство беспартийных депутатов, чаще всего представителей несистемной оппозиции. Значительно увеличили свое представительство «Яблоко» и КПРФ, однако выиграли лишь в 2 и 1 муниципальном округах соответственно (из 84).

Таким образом, общей особенностью выборов в двух крупнейших городах России стал незначительный спад представительства «Единой России». В отличие от Москвы, в Санкт-Петербурге у «Единой России» оказались более стабильные позиции. Следует отметить, что на выборах в Мосгордуму стало широко применяться электронное голосование.

\title{
Список литературы
}

Барсукова С.Ю., Ионова Д., Сафиуллина Ю. 2020. Мобилизация студентовагитаторов во время предвыборной кампании Сергея Собянина на пост мэра Москвы в 2018 году. - ЭКО. № 2. С. 158-171.

BOCHKAEV Alu Rizvanovich, Master's Degree student of the Faculty of Sociology and Political Science, Financial University under the Government of the Russian Federation (49 Leningradsky Ave, GSP-3, Moscow, Russia, 125993; dzyudoistalu@mail.ru)

\section{FEATURES AND COMPARATIVE CHARACTERISTICS OF POLITICAL CAMPAIGNS IN MOSCOW AND ST. PETERSBURG}

\begin{abstract}
Russia will hold elections to the State Duma in 2021, in this connection, it is necessary to recall the events that took place within the framework of major regional elections of previous years. The election of the governor of St. Petersburg (2019) was an event when the representative of «United Russia» won in the face of protest moods (including because of the pension reform), but the competition in the councils of municipalities significantly increased. In the Moscow City Duma elections (2019) the Communist Party, "Yabloko» and "Fair Russia» significantly increased their representation in Moscow, while maintaining the absolute majority of "United Russia». Also in these elections, the practice of remote electronic voting (DEG) began, which became a new technology for the practice of administrative resource.
\end{abstract}

Keywords: elections, Moscow City Duma, municipal districts, electronic voting, administrative resource

\footnotetext{
1 Муниципалитеты подвели итоги выборов. - Коммерсант. Доступ: https://www.kommersant.ru/doc/4103201 (проверено 23.03.2021).
} 